\title{
Reserve Carbohydrates and Lipids from the Seeds of Four Tropical Tree Species with Different Sensitivity to Desiccation
}

\author{
Juliana Iura de Oliveira Mello ${ }^{1}$, Claudio José Barbedo ${ }^{1}$, Antonio Salatino ${ }^{2}$ and Rita de \\ Cássia Leone Figueiredo-Ribeiro ${ }^{1^{*}}$ \\ ${ }^{1}$ Instituto de Botânica; Secretaria do Meio Ambiente do Estado de São Paulo; C. P.: 3005; 01061-970; São Paulo - \\ SP - Brasil. ${ }^{2}$ Departamento de Botânica; Instituto de Biociências; Universidade de São Paulo; C. P.: 11461; 05422- \\ 970; São Paulo - SP - Brasil
}

\begin{abstract}
Considering the importance of water content for the conservation and storage of seeds, and the involvement of soluble carbohydrates and lipids for embryo development, a comparative study was carried out among the seeds of Inga vera (ingá), Eugenia uniflora (pitanga), both classified as recalcitrant, and Caesalpinia echinata (brazilwood) and Erythrina speciosa (mulungu), considered as orthodox seeds. Low concentrations of cyclitols (0.3-0.5\%), raffinose family oligosaccharides (ca. 0.05\%) and unsaturated fatty acids (0-19\%) were found in the seeds of ingá and pitanga, while larger amounts of cyclitols (2-3\%) and raffinose (4.6-13\%) were found in brazilwood and mulungu, respectively. These results, in addition to higher proportions of unsaturated fatty acids (53-71\%) in orthodox seeds, suggested that sugars and lipids played important role in water movement, protecting the embryo cell membranes against injuries during dehydration.
\end{abstract}

Key words: Desiccation tolerance, Fatty acids, Seeds, Starch, Sugars

\section{INTRODUCTION}

The storage of seeds is an important tool in the ex situ conservation of plant species. However, it is necessary to understand the seed behavior with respect to tolerance to desiccation and freezing in order to improve the preservation of seed viability during storage. In general, seeds accumulate large amounts of storage compounds such as carbohydrates, proteins and oils that represent the main source of nutrients for the initial seedling growth (Mayer and Poljakoff-Mayber, 1989) and also for the nutrition of animals and humans. The knowledge of seed biology provides tools for improving the agricultural practices and managing genetic resources (Santos-Mendoza et al., 2008). Among various cellular attributes, desiccation and freezing tolerance have been focused on storage compounds. Compatible solutes, including many sugars and sugar alcohols, are synthesized by the plants in response to desiccation and low temperature, among other stressing conditions. These compounds are thought to stabilize the sensitive cellular components during drying and freezing (Hincha et al., 2006) and also act as osmoprotectans, improving the water status and

*Author for correspondence: ritarib@usp.br 
the cell volume in the frozen state (Crowe et al., 1990).

Plant oils can provide renewable sources of highvalue fatty acids for both the chemical and healthrelated industries (Dyer et al., 2008) and also can protect the plant cells against stressing conditions. For instance, an increase in unsaturated fatty acids was observed for the plants of Vigna unguiculata subjected to water stress (Paula et al., 1990). The effects of dehydration were firstly detected in the membrane composition (Navari-Izzo et al. 1989) and this was observed in the leaves of Sporolobus stafianus, known as resurrection plant. In this species, a drastic reduction in total lipids and in the amount of unsaturated fatty acids was observed after decreasing the water content (Quartacci et al., 1997).

The seeds of Erythrina speciosa Andr. (Leguminosae, Faboideae), like those from $E$. caffra (Nkang 2002), are remarkably tolerant to desiccation and can be stored for several years in a range of environmental conditions in the dried state (data not published). From the same plant family, the seeds of Caesalpinia echinata Lam. (Caesalpinioideae) are also tolerant to desiccation (Barbedo et al., 2002). However, these seeds loose their viability within three months when stored under the laboratory conditions and maintain high germinability under sub-zero conditions up to two years (Hellmann et al., 2006). The seeds of Inga vera Will. subsp. affinis (DC.) T.D. Pennington (Mimosoideae, Leguminosae) are classified as recalcitrant and have one of the shortest storability known (Bilia and Barbedo, 1997). Indeed, these seeds can be stored only up to seven days without utilization of artificial methods (Bilia et al., 1999). The storage of hydrated embryos in polyethylene glycol (PEG) solution was capable of maintaining high germinability until 30 days of storage at -1.7 $\mathrm{MPa}$ and $5^{\circ} \mathrm{C}$ (Faria et al., 2006) and 90 days at -2.4 MPa and $10{ }^{\circ} \mathrm{C}$ (Andréo et al., 2006). The seeds of Eugenia uniflora L. (Myrtaceae) also exhibit short storability, but higher than I. vera, and could be stored for six months under controlled conditions (Barbedo et al., 1998). Among other Eugenia species, E. uniflora seeds are the most tolerant, keeping their germinability with moisture content of $20 \%$ (Delgado and Barbedo, 2007).

In the present work, the content and composition of reserve carbohydrates and lipids from the seeds of these four tropical tree species presenting different degrees of tolerance to desiccation, were analyzed aiming at a better understanding of the involvement of these compounds with the cellular protection against drying.

\section{MATERIALS AND METHODS}

Mature fruits of I. vera Will subsp. affinis (DC.) T. D. Pennington, E. uniflora L., C. echinata Lam. (Borges et al., 2005) and Erythrina speciosa Andr. were harvested in 2006 from plantations located at the Botanical Garden in São Paulo (SP, Brazil) $23^{\circ} 38^{\prime} \mathrm{S}-46^{\circ} 37^{\prime} \mathrm{W}-$ and in the "Reserva Biológica e Estação Experimental de Moji-Guaçu" (SP, Brazil) $-22^{\circ} 15^{\prime} \mathrm{S}-47^{\circ} 8^{\prime} \mathrm{W}$. After the harvest, the fruits were transferred to the "Instituto de Botânica" and the seeds were extracted and mixed at random. The water content ( $g$ water per $g$ dry matter $-\mathrm{g} \mathrm{g}^{-1}$ ) was determined (four replicates of five seeds) gravimetrically (oven at $103{ }^{\circ} \mathrm{C} \pm 3{ }^{\circ} \mathrm{C}$ for17h) according to ISTA (1985). The germination tests were carried out in germination chambers (Marconi MA400) at $25 \pm 1{ }^{\circ} \mathrm{C}$, under $12 \mathrm{~h}$ photoperiod, in paper roll moistened previously with tap water, with four replications of 12 seeds (Mello and Barbedo, 2007). The germination was evaluated every two days from the sowing day, by registering the protrusion of the primary root (at least $5 \mathrm{~mm}$ ). The number of seedlings with normal development of both radicular system and shoots was also registered.

Three replications of five embryos from the seeds of each species were separated and analyzed for soluble carbohydrates and starch. For $C$. echinata and E. speciosa, the tissues were separated into embryonic axis and cotyledons. Immediately after the excision, both the tissues were weighed, boiled in $80 \%$ ethanol $(\mathrm{v} / \mathrm{v})$, homogenized with a mortar and pestle, and heated at $80{ }^{\circ} \mathrm{C}$ for $10 \mathrm{~min}$. After centrifugation for $5 \mathrm{~min}$ at $1000 \mathrm{~g}$, the residue was re-extracted twice with $80 \%$ ethanol for $5 \mathrm{~min}$ at $80{ }^{\circ} \mathrm{C}$. The extracts obtained were analyzed colorimetrically by the phenol-sulfuric method (Dubois et al., 1956) for total carbohydrate determination, using glucose as standard and were expressed as mg per $\mathrm{g}$ of dry mass $\left(\mathrm{mg} \mathrm{g}^{-1} \mathrm{DM}\right)$. Neutral soluble carbohydrates were analyzed by high performance anion exchange chromatography coupled with pulsed amperometric detection (HPAEC/PAD) after deionization through a column consisting of equal amounts of Dowex-1 $\left(\mathrm{Cl}^{-}\right.$form $)$and Dowex-50W $\left(\mathrm{H}^{+}\right.$form). The HPAEC/PAD system (Dionex ICS-3000) used 
consisted of a 4 x $250 \mathrm{~mm}$ CarboPac PA-1 column and a gradient of $250 \mathrm{mM}$ sodium hydroxide (eluent B) and water (eluent A) with the following programme: 0-2 min, $7 \%$ eluent $B ; 2.1-25 \mathrm{~min}, 4 \%$ eluent B; 25.1-30 min, 80\% eluent B; 30.1-35 min,

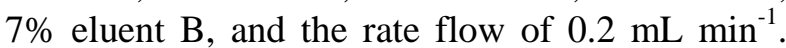
The residue of soluble carbohydrate extraction was subjected to enzymatic determination of starch according to Amaral et al. (2007).

Total lipids were extracted from the powdered material (0.2-2 g DM) using soxhlet and hexane as solvent during four hours. After the extraction, the solvent was evaporated and yield was calculated. The oil extracted was saponified and methylesterified according to Mayworm et al. (1998), with modifications. The methyl esters were separated and analyzed in a gas chromatograph (Agilent 6890 series) with a mass spectrometry (Agilent 5973 Network) on a $30 \mathrm{~m}$ X $0.35 \mathrm{~mm}$ column HP5 with silica, temperature range from $160{ }^{\circ} \mathrm{C}$ increasing $5{ }^{\circ} \mathrm{C} \mathrm{min}^{-1}$ during three minutes and $5{ }^{\circ} \mathrm{C} \min ^{-1}$ until $175{ }^{\circ} \mathrm{C}$, followed an increase of $1.5^{\circ} \mathrm{C} \mathrm{min}-1$ until $195{ }^{\circ} \mathrm{C}$ and finally, an increase of $10{ }^{\circ} \mathrm{C} \mathrm{min}^{-1}$ until $300{ }^{\circ} \mathrm{C}$ for five minutes. The peaks of concentration in each case from the unknown samples were compared with the library and were matched. The percentage of fatty acid constituents were obtained by the display unit of the instrument.

\section{RESULTS}

The water content of mature seeds of E. speciosa and $C$. echinata at harvesting were 0.138 and $0.388 \mathrm{~g} \mathrm{~g} \mathrm{~g}^{-1} \mathrm{DM}$, respectively, and the water content of seeds from E. uniflora and $I$. vera were 1.236 and $1.214 \mathrm{~g} \mathrm{~g}^{-1} \mathrm{DM}$, respectively. The germination percentages of $E$. speciosa, $E$. uniflora and I. vera did not differ among them but were significantly higher than that of $C$. echinata (Table 1). However, the development of normal seedling did not differ among the four analyzed species. The analysis of total soluble carbohydrates showed higher amounts in the embryonic axis of E. speciosa seeds (28\% DM), followed by the cotyledons of the same species and cotyledons and axis of seeds from $C$. echinata (ca. 14\%). Intermediate values were obtained for the embryos of E. uniflora and the lowest amount was found in the embryos $(0.6 \%)$ from I. vera (Table 2).

The quantification of starch showed that the seeds of E. speciosa were poor in this reserve compound, as also the axis of C. echinata (0.7$2.3 \%$ DM). However, the cotyledons of $C$. echinata and embryos of I. vera presented more than $42 \% \mathrm{DM}$ as starch. Among the analyzed species, the highest content of starch was found in the embryos of E. uniflora, representing ca. $64 \%$ of the seed dry matter (Table 2). The cotyledons of E. speciosa contained high amounts of lipids (more than 23\% DM) when compared to the other analyzed species and tissues, followed by $C$. echinata cotyledons (more than 17\% DM). The embryonic axes of both the species showed lower contents of lipids (7-12\%) than those of their cotyledons. In contrast, the embryos of E. uniflora and $I$. vera presented less than $1 \%$ of lipids in the seed dry mass basis (ca. 0.8 and $0.3 \%$, respectively).

The analysis of soluble carbohydrates by HPAEC/PAD showed similar composition in both the axis and cotyledons of seeds from the four tropical tree species. Sucrose was the major sugar present in all the seeds (Fig. 1), except E. speciosa with high amounts of the raffinose family oligosaccharides (RFOs). Sucrose contents in the seeds of E. uniflora and I. vera were lower when compared to the other analyzed species (Table 3), but was the main sugar found in the seeds of $C$. echinata, presenting the highest amounts in the cotyledons ( $c a .12 \%$ DM). Table 3 also shows that raffinose was the predominant carbohydrate in $E$. speciosa, representing more than $13 \% \mathrm{DM}$ of the embryonic axis. RFOs were absent or were detected in minute proportions in the other studied species. Cyclitols were present in higher proportions in C. echinata tissues (2-3\%), being 10 times the values found in the other species. Little amounts of monosaccharide (lower than $0.2 \%$ ) such as glucose and fructose were found in all the analyzed tissues (Table 3), except E. uniflora. 
Table 1 - Physiologycal parameters of seeds from four tropical tree species harvested at maturity. Means \pm sd.

\begin{tabular}{lccccc}
\hline \multicolumn{1}{c}{ Species } & $\begin{array}{c}\text { Moisture content } \\
\left(\mathbf{g ~ g ~}^{-\mathbf{1}} \mathbf{D M}\right)\end{array}$ & $\begin{array}{c}\text { Fresh mass } \\
\left.\text { (g seed }^{-1}\right)\end{array}$ & $\begin{array}{c}\text { Dry mass } \\
\left.\text { (g seed }^{-1}\right)^{11}\end{array}$ & $\begin{array}{c}\text { Germination } \\
(\boldsymbol{\%})\end{array}$ & $\begin{array}{c}\text { Seedling } \\
(\boldsymbol{\%})\end{array}$ \\
\hline Erythrina speciosa & $0.138 \pm 0.020$ & $0.31 \pm 0.04$ & $0.27 \pm 0.03$ & $100.0 \pm 0.0$ & $100.0 \pm 0.0$ \\
Caesalpinia echinata & $0.388 \pm 0.018$ & $0.28 \pm 0.03$ & $0.19 \pm 0.22$ & $89.6 \pm 8.0$ & $85.4 \pm 10.5$ \\
Eugenia uniflora & $1.236 \pm 0.062$ & $0.39 \pm 0.09$ & $0.18 \pm 0.05$ & $100.0 \pm 0.0$ & $95.0 \pm 6.4$ \\
Inga vera & $1.214 \pm 0.034$ & $0.65 \pm 0.07$ & $0.29 \pm 0.02$ & $100.0 \pm 0.0$ & $100.0 \pm 0.0$ \\
\hline
\end{tabular}

Table 2 - Overall soluble carbohydrate, starch ( $\left.\mathrm{mg} \mathrm{g}^{-1} \mathrm{DM}\right)$ and lipids (\%) in seeds of four tropical tree species with different sensitivity to desiccation. Within each column, means followed by the same letter do not differ significantly (Tukey's test, $\mathrm{P}=0.05, \mathrm{n}=3$ )

\begin{tabular}{lcccc}
\hline \multicolumn{1}{c}{ Species } & Tissues & $\begin{array}{c}\text { Soluble carbohydrate } \\
\left(\mathbf{m g ~ g}^{-1} \mathbf{D M}\right)\end{array}$ & $\begin{array}{c}\text { Starch } \\
\left(\mathbf{m g ~ g}^{-1} \mathbf{D M}\right)\end{array}$ & $\begin{array}{c}\text { Total lipids } \\
(\boldsymbol{\%})\end{array}$ \\
\hline Erythrina speciosa & Cotyledons & $137.76 \mathrm{~b}$ & $7.77 \mathrm{c}$ & $23.29 \mathrm{a}$ \\
& Axis & $285.18 \mathrm{a}$ & $15.40 \mathrm{c}$ & $12.31 \mathrm{c}$ \\
Caesalpinia echinata & Cotyledons & $148.37 \mathrm{~b}$ & $420.35 \mathrm{~b}$ & $17.57 \mathrm{~b}$ \\
& Axis & $140.63 \mathrm{~b}$ & $22.79 \mathrm{c}$ & $7.04 \mathrm{~d}$ \\
Eugenia uniflora & Whole embryo & $70.10 \mathrm{c}$ & $641.03 \mathrm{a}$ & $0.84 \mathrm{e}$ \\
Inga vera & Whole embryo & $60.90 \mathrm{c}$ & $514.61 \mathrm{~b}$ & $0.27 \mathrm{f}$ \\
\hline CV $(\%)$ & & 14.21 & 16.67 & 2.22 \\
\hline
\end{tabular}

The relative composition of fatty acids varied among the analyzed species, showing higher diversity in the tissues from $C$. echinata and $E$. speciosa seeds. In the embryos of $I$. vera and $E$. uniflora predominantly palmitic (C16:0) and stearic (C18:0) (saturated fatty acids) were detected. The main fatty acid found in C. echinata tissues was the linoleic acid (C18:2), representing ca. $25 \%$ of the total lipid, while in E. speciosa the oleic acid (C18:1) constituted $c a .50 \%$ of the total lipids from the cotyledons (Table 4).
Figure 2 showed that the proportion of unsaturated fatty acids increased with the potential tolerance to desiccation presented by the analyzed seeds. The embryos of the recalcitrant seeds of I. vera and $E$. uniflora showed $100 \%$ or more than $80 \%$ of the total lipid content as saturated fatty acids, respectively. The proportions of unsaturated and saturated fatty acids were similar in the seeds of $C$. echinata while in the cotyledons of E. speciosa, the amounts of unsaturated fatty acids were much higher, figuring more than $70 \%$ of the total fatty acids detected.

Table 3 - Composition of soluble neutral carbohydrates $\left(\mathrm{mg} \mathrm{g}^{-1} \mathrm{DM}\right)$ in seeds of four tropical tree especies with different sensitivity to desiccation. $\mathrm{Cyl}=$ cyclitols; $\mathrm{Glu}=$ glucose; Fru = fructose; Suc = sucrose; Raf = raffinose; $\mathrm{Sta}=$ stachyose. Within each column, means followed by the same letter do not differ significantly (Tukey's test, $\mathrm{P}=0.05, \mathrm{n}=3)$.

\begin{tabular}{lccccccc}
\hline \multirow{2}{*}{ Species } & \multirow{2}{*}{ Tissues } & \multicolumn{6}{c}{ Soluble carbohydrates $\left(\mathbf{m g ~ g}^{-\mathbf{1}} \mathbf{D M}\right)$} \\
\cline { 3 - 8 } & & Cyl & Glu & Fru & Suc & Raf & Sta \\
\hline \multirow{2}{*}{ E. speciosa } & Cotyledons & $3.42 \mathrm{~d}$ & $0.22 \mathrm{~b}$ & $0.19 \mathrm{~b}$ & $37.27 \mathrm{~d}$ & $45.86 \mathrm{~b}$ & $37.17 \mathrm{a}$ \\
& Axis & $9.76 \mathrm{c}$ & $0.64 \mathrm{~b}$ & $0.55 \mathrm{~b}$ & $106.28 \mathrm{~b}$ & $130.79 \mathrm{a}$ & $13.04 \mathrm{~b}$ \\
C. echinata & Cotyledons & $20.52 \mathrm{~b}$ & $2.04 \mathrm{~b}$ & $1.13 \mathrm{~b}$ & $120.64 \mathrm{a}$ & $2.12 \mathrm{c}$ & $1.72 \mathrm{c}$ \\
& Axis & $32.27 \mathrm{a}$ & $2.32 \mathrm{~b}$ & $1.21 \mathrm{~b}$ & $95.90 \mathrm{~b}$ & $5.46 \mathrm{c}$ & $3.91 \mathrm{c}$ \\
E. uniflora & Whole embryo & $3.54 \mathrm{~d}$ & $5.98 \mathrm{a}$ & $10.25 \mathrm{a}$ & $50.22 \mathrm{c}$ & $0.49 \mathrm{c}$ & $0.11 \mathrm{c}$ \\
Inga vera & Whole embryo & $5.94 \mathrm{~cd}$ & $1.32 \mathrm{~b}$ & $1.57 \mathrm{~b}$ & $51.67 \mathrm{c}$ & $0.52 \mathrm{c}$ & $0.00 \mathrm{c}$ \\
\hline CV $(\%)$ & & 15.39 & 43.66 & 33.18 & 5.69 & 8.07 & 30.58 \\
\hline
\end{tabular}



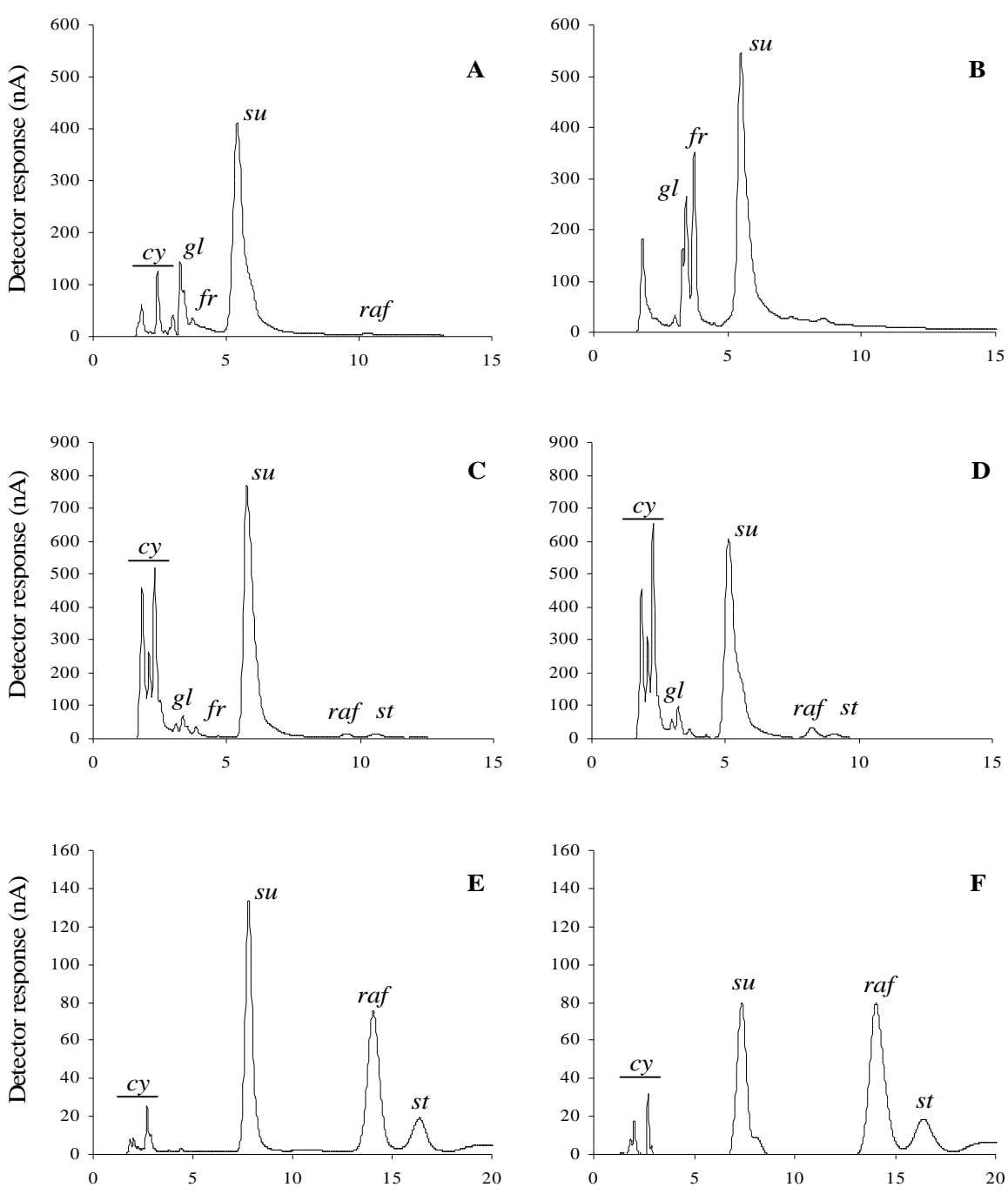

Retention time (min)

Figure 1 - HPAEC/PAD of neutral soluble carbohydrates of mature seeds from Inga vera (A), Eugenia uniflora (B), Caesalpinia echinata - embryonic axis (C) and cotlyledons (D) - and Erythrina speciosa - embryonic axis (C) and cotyledons (D). cy - cyclitols, $g l$ glucose, $f r$ - fructose, suc - sucrose, raf - raffinose and $s t$ - stachyose.

Table 4 - Relative composition of fatty acids (\%) from storage lipids in seeds of four tropical tree species with different sensitivity to desiccation.

\begin{tabular}{|c|c|c|c|c|}
\hline Fatty acid (\%) & E. speciosa * & C. echinata* & I. vera & E. uniflora \\
\hline Palmitic (C16:0) & 18.95 & 13.00 & 66.55 & 57.38 \\
\hline Stearic (C18:0) & 6.47 & 25.70 & 26.66 & 10.10 \\
\hline Oleic (C18:1) & 51.77 & 7.90 & 0.00 & 17.23 \\
\hline Linoleic (C18:2) & 18.56 & 45.40 & 0.00 & 2.21 \\
\hline Arachidic (C20:0) & 1.84 & 4.10 & 1.38 & 7.89 \\
\hline Eicosenoic (C20:1) & 0.68 & 0.10 & 0.00 & 0.00 \\
\hline Behenic (C22:0) & 1.48 & 3.40 & 0.95 & 2.89 \\
\hline Lignoceric (C24:0) & 0.24 & 0.40 & 4.46 & 2.30 \\
\hline
\end{tabular}

*Values correspond to cotyledons only. 


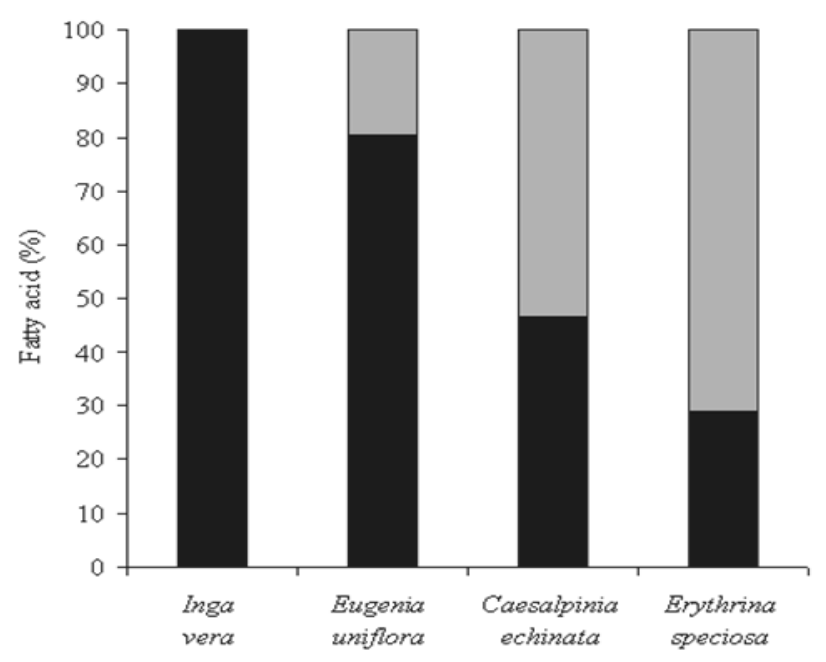

Figure 2 - Percentage of saturated (black column) and unsaturated (gray column) fatty acids in storage lipids from seeds of tropical tree species with different sensitivity to desiccation.

\section{DISCUSSION}

Recalcitrant seeds are usually shed at water contents greater than $0.40 \mathrm{~g}$ water per $\mathrm{g}$ dry matter $\left(\mathrm{g} \mathrm{g}^{-1}\right)$ and lose vigor with relatively little drying, while orthodox seeds are shed with low water content and can withstand the dehydration to as low as $0.05 \mathrm{~g} \mathrm{~g}^{-1}$ (Sershen et al., 2008). The present results showed higher water contents in mature seeds of $I$. vera and E. uniflora, the more sensitive species to desiccation, in contrast to what was found in the less sensitive ones from $C$. echinata and E. speciosa, both previously considered as orthodox seeds (Barbedo et al., 2002; Nkang, 2002). While seed longevity appears to be a consequence of metabolic activity, desiccation sensitivity can be ameliorated by protection mechanisms that may not affect the storage life span of a given species (Sershen et al., 2008). Thus, at the same environmental condition, it would be possible to find the desiccation tolerant seeds with shorter lifespan than desiccation intolerant ones, as found between the tolerant $C$. echinata and both intolerant $E$. involucrata and $E$. brasiliensis seeds (Barbedo et al., 2002; Kohama et al., 2006). Therefore, associations between both the processes deserve more attention.

The differences found in water content were not related with the germination potential of the seeds analyzed in the present work. The seeds of $C$. echinata presented germination percentage lower than that of other analyzed species. However,
Hellmann et al. (2006) have reported higher values for the seeds harvested from the same plantation of C. echinata. Therefore, the differences found could be attributed to the seasonal differences in environmental conditions rather than to genetic factors. The high germinability found in the seeds of E. uniflora and I. vera seeds was consistent with the current literature and with the fact that they were commonly indicated for reforestation (Bilia and Barbedo, 1997).

Concerning the carbohydrate quantification, it was possible to separate the studied species into two groups, one including the desiccation tolerant seeds, E. speciosa and C. echinata (Nkang, 2002; Barbedo et al., 2002), both with more than 14\% DM as soluble carbohydrates, and the other group represented by E. uniflora and I. vera seeds, with recalcitrant behavior (Delgado and Barbedo, 2007; Bonjovani and Barbedo, 2008) and lower amounts of soluble carbohydrates. A variety of orthodox seeds, including mature legumes, can contain high levels of soluble carbohydrate. Glycine max (soybean) comprised 14 and $28 \%$ of the dry matter of the axis and cotyledons, respectively (Górecki et al., 2001). According to Pritchard et al. (1995), the intolerance of recalcitrant seeds to desiccation could be related to the low values of soluble carbohydrates contained by the seeds, which was reinforced by the present results relative to $E$. uniflora and I. vera, containing 7 and 6\% sugars, respectively. 
Among the soluble carbohydrates, sucrose is mostly accumulated in the seeds and is thought to play a major role in cellular desiccation tolerance (Hincha et al., 2006). However, this sugar was found in large proportions in the seeds of the four species analyzed in the present study, independently of their tolerance to desiccation and storage behavior. Other compounds have been involved in the acquisition of tolerance to dehydration, including LEA proteins (Barbedo and Marcos Filho, 1998 and references therein), amino acids (e.g. proline), raffinose family oligosaccharides (RFO) and sugar alcohols (Yancey et al., 1982). In C. echinata seeds, RFO was present in very low proportions (less than $0.5 \%$ ), confirming previous reports (Garcia et al., 2006; Hellmann et al., 2008), while cyclitols were found in larger amounts, mainly in the embryonic axis (ca. 3\%), and might play a protective role during the desiccation and loss of water during seed maturation (Borges et al., 2006), replacing water and stabilizing membranes and other sensitive systems, as proposed for other legume seeds (Peterbauer and Richter, 2001). E. speciosa seeds presented RFO as the principal soluble carbohydrates, especially raffinose, in proportion equivalent to that of sucrose ( $\mathrm{ca}$. $4 \%)$. In general, there are differences in the quantities of RFO members in seeds from different species, particularly in legumes (Górecki et al., 2001) and this could be related to their behavior during storage. According to Horbowicz and Obendorf (1994), seed storability depends on the ratio of sucrose to oligosaccharides. Seeds with sucrose: oligosaccharide ratio lower than 1.0 have a storability half-viability period higher than 10 years, whereas those with ratio higher than 1.0 have storability half-viability period lower than 10 years. Therefore, the interactions of these carbohydrates during the storage in desiccation tolerant tissues might promote the hydration of membrane phospholipids, maintaining the conformation and functionality of cell membranes during water loss (Hoekstra et al., 2001). In addition to sucrose $(5 \%)$, desiccation intolerant seeds of $I$. vera and E. uniflora presented only traces of cyclitols and RFO, which probably contributed to the loss of viability after drying and storage of the seeds. In combination with data in the literature these results showed that the ratio of sucrose to oligosaccharides in seed tissues could provide useful information on the seed storage category.

The small proportion of starch in the embryonic axis of the orthodox seeds (less than 2\%) could be compensated by the larger amounts of soluble carbohydrates found (14-28\%), which were more easily metabolized and could be readily used in the germination process. This positive association between the soluble carbohydrates and seed storability/desiccation tolerance could not be applied to starch contents since the seeds with extremely different sensitivity to desiccation $(C$. echinata, I. vera and $E$. uniflora) presented relatively high (42 to 64\%) and similar percentage of starch. For most grain and legumes, the largest part of the carbohydrate fraction was starch (Table 5), accounting for about $35-45 \%$ of the seed weight (Hedley, 2001).

The oil content in the seeds of the starch storing legumes is not usually higher than about $2 \%$. On the other hand, in the seeds storing high levels of oil, such as soybean, starch only makes up about $1.5 \%$ of the seed weight (Hedley, 2001). However, the lipid amounts found in the embryonic axis of $C$. echinata and E. speciosa were relatively high (7-12\%) and were similar to the values obtained in the seeds of E. velutina, a species from the Brazilian Caatinga (Mayworm et al., 1998); the cotyledons of E. speciosa showed the same contents ( $c a .23 \%)$ as the seeds of $C$. pyramidalis (Mayworm et al., 1998). The orthodox seeds of some species of Citrus can contain more than $50 \%$ of lipids (Hor et al., 2005), which has also been reported for the seeds of Dalbergia miscolobium from the Cerrado which are very rich in oil (Silva et al., 1998). On the other hand, the desiccation intolerant seeds of Inga sp. presented only traces of lipids (Pritchard et al., 1995), which was consistent with the very low values found in the present work for the seeds of E. uniflora and $I$. vera (lower than $0.8 \%$ ). These results reinforced the suggestion that high proportions of lipids could be involved in the mechanism of tolerance to desiccation. 
Table 5 - Starch, lipids and fatty acid composition of seeds from some tropical legumes.

\begin{tabular}{|c|c|c|c|c|c|}
\hline Species & $\begin{array}{c}\text { Starch } \\
(\%)\end{array}$ & $\begin{array}{c}\text { Lipids } \\
(\%)\end{array}$ & & acid & Reference \\
\hline Vigna radiata & - & 1.40 & $\begin{array}{l}18: 1 \\
18: 2\end{array}$ & $\begin{array}{l}26.4 \\
41.2\end{array}$ & Anwar et al., 2007 \\
\hline Phaseolus vulgaris & 41.50 & 1.50 & - & & Hedley, 2001 \\
\hline Cassia floribunda & - & 2.60 & - & & Vadiel \& Janardh anan, 2001 \\
\hline Pisum sativum & 45.00 & 2.70 & - & & Hedley, 2001 \\
\hline Hymenae a stigonocarpa & - & 5.30 & $\begin{array}{l}16: 0 \\
18: 0 \\
18: 1 \\
18: 2 \\
18: 3 \\
20: 0\end{array}$ & $\begin{array}{c}8.9 \\
4.7 \\
31.6 \\
52.3 \\
1.2 \\
0.8\end{array}$ & Matuda \& Maria Netto, 2005 \\
\hline Cicer arietinum & 44.40 & 5.20 & - & & Sotelo, 1996 \\
\hline Hymenae a courbaril & - & 8.59 & - & & Pinto et al., 2005 \\
\hline Bauhinia variegata & - & 16.61 & $\begin{array}{l}16: 0 \\
18: 0 \\
18: 2 \\
20: 0\end{array}$ & $\begin{array}{c}19.69 \\
13.98 \\
56.98 \\
1.08\end{array}$ & \\
\hline Bauhinia forficata & - & 19.45 & $\begin{array}{l}18: 2 \\
16: 0 \\
18: 0 \\
20: 1\end{array}$ & $\begin{array}{c}46.47 \\
19.27 \\
13.89 \\
0.51\end{array}$ & Faria et al., 2004 \\
\hline Glycine $\max$ & 1.50 & 19.70 & - & & Hedley, 2001 \\
\hline Glycine $\max$ & - & 20.60 & - & & Moraes et al., 2006 \\
\hline Glycine max & - & 16.62 & - & & Marega Filho et al., 2001 \\
\hline Mimosa grahamii & - & 23.50 & - & & Ortega-Nieblas et al., 1996 \\
\hline Lonchocarpus muehlbergianus & - & 26.80 & $\begin{array}{l}16: 0 \\
18: 0 \\
18: 1 \\
18: 2 \\
18: 3\end{array}$ & $\begin{array}{c}11.65 \\
5.80 \\
56.00 \\
10.90 \\
12.90\end{array}$ & Vallilo et al., 2001 \\
\hline Dipteryx alata & - & 38.20 & $\begin{array}{l}18: 0 \\
18: 1 \\
18: 2 \\
20: 0 \\
20: 1 \\
22: 0 \\
24: 0\end{array}$ & $\begin{array}{c}5.40 \\
50.40 \\
28.00 \\
1.07 \\
2.70 \\
2.60 \\
2.10\end{array}$ & Takemo to et al., 2001 \\
\hline Caesalpinia peltophoroides & - & 50.00 & - & & Corte et al., 2006 \\
\hline
\end{tabular}

The value and application of particular oil is determined largely by its fatty acid composition, and while most vegetable oils contain just five basic fatty acid structures, there is a rich diversity of fatty acids present in nature, many of which have potential usage in industry (Dyer et al., 2008). In the present study, the unsaturated fatty acids, oleic (C18:1) and linoleic acid (C18:2) were the major components of the oil from the seeds of $E$. speciosa and $C$. echinata. The seeds of $E$. speciosa presented $c a$. $50 \%$ of oleic acid, similar to E. velutina seeds (Mayworm et al., 1998) and the proportion of linoleic acid in C. echinata seeds $(45 \%)$ was similar to that reported for the seeds of C. pyramidalis (Mayworm et al., 1998). In addition to the taxonomic features, these 
similarities could be related with seed behavior as observed by Liu et al. (2006). They emphasized that the orthodox seeds presented higher proportion of linoleic acid (C18:2) than the recalcitrant seeds, in which the predominant fatty acid was the linolenic acid (C18:3). Additionally, recalcitrant seeds exhibited higher fatty acid saturation in the phospholipids and higher phase transition temperature when compared to orthodox seeds (Liu et al., 2006). Thus, it would be interesting to study the differences in the lipid composition among the seeds from the species with different desiccation tolerance levels, but into the same genus, e.g. Eugenia species as demonstrated by Delgado and Barbedo (2007). Taking altogether, the present results suggested that lipids stored in the analyzed seeds could play, in addition to sugars, an important role in the water movement, protecting the embryo cell membranes against the injuries during seed dehydration.

\section{ACKNOWLEDGEMENTS}

This work is part of J. I. O. Mello Master Thesis in the Plant Biodiversity and Environment Program/Instituto de Botânica, SEMASP, São Paulo and was supported by the State of São Paulo Research Foundation (FAPESP, Grant 05/041397). J.I.O.Mello thanks $\mathrm{CNPq}$ for the Master fellowship. The authors thank $\mathrm{CNPq}$ for the technical fellowship to M.P. Monteiro. A. Salatino, C.J. Barbedo and R.C.L. FigueiredoRibeiro are researchers associated with CNPq.

\section{RESUMO}

Os compostos de reserva das sementes, além de suprirem energia para o desenvolvimento embrionário, desempenham importantes funções relacionadas à proteção celular contra secagem e congelamento. Considerando a importância do teor de água para a conservação e para o armazenamento de sementes de espécies arbóreas e o envolvimento dos carboidratos solúveis e de lipídios nesses processos, foi realizada uma análise comparativa desses compostos em sementes de Inga vera (ingá) e Eugenia uniflora (pitanga), consideradas recalcitrantes, e em Caesalpinia echinata (pau-brasil) e Erythrina speciosa (mulungu), com comportamento ortodoxo. Baixas concentrações de ciclitóis $(0,3-0,5 \%)$, de oligossacarídeos da série da rafinose $(0,05 \%)$ e de ácidos graxos insaturados (0-19\%) foram encontradas em sementes de ingá e pitanga, enquanto maiores quantidades de ciclitóis (2-3\%) e de rafinose $(4,6-13 \%)$ foram encontradas nas sementes de pau-brasil e mulungu, respectivamente. Estes resultados, juntamente com as altas proporções de ácidos graxos insaturados (53-71\%) presentes em sementes de pau-brasil e mulungu, sugerem que os açúcares e os lipídios poderiam desempenhar papel importante no movimento de água, protegendo as membranas celulares embrionárias contra injúrias provocadas durante a dessecação.

\section{REFERENCES}

Amaral, L. I. V.; Gaspar, M.; Costa, P. M. F.; Aidar, M. P. M.; Buckeridge, M. S. (2007), Novo método enzimático rápido e sensível de extração e dosagem de amido em materiais vegetais. Hoehnea, 34, 425431.

Andréo, Y.; Nakagawa, J.; Barbedo, C. J. (2006), Mobilização de água e conservação da viabilidade de embriões de sementes recalcitrantes de ingá (Inga vera Will. subsp. affinis (DC.) T.D. Pennington). Rev Bras Bot, 29, 309-318.

Anwar, F.; Latif, S.; Przybylski, R.; Sultana, B.; Ashraf, M. (2007), Chemical composition and antioxidant activity of seeds of different cultivars of mungbean. $J$ Food Sci, 72, 5503-5510.

Barbedo, C. J.; Marcos-Filho, J. (1998), Tolerância à dessecação em sementes. Acta Bot. Bras., 12, 145164.

Barbedo, C. J.; Kohama, S.; Maluf, A. M.; Bilia, D. A. C. (1998), Germinação e armazenamento de diásporos de cerejeira (Eugenia involucrata DC. Myrtaceae) em função do teor de água. Rev Bras Sementes, 20, 184-188.

Barbedo, C. J.; Bilia, D. A.; Figueiredo-Ribeiro, R. C. L. (2002), Tolerância à dessecação e armazenamento de sementes de Caesalpinia echinata Lam. (paubrasil), espécie da Mata Atlântica. Rev Bras Bot, 25, 431-439.

Bilia, D. A. C., Barbedo, C. J. (1997), Estudos da germinação e armazenamento de sementes de Inga uruguensis Hook. et Arn. Científica, 25, 379-391.

Bilia, D. A. C.; Marcos-Filho, J.; Novembre, A. D. C. L. (1999), Desiccation tolerance and seed storability of Inga uruguensis (Hook et Arn.). Seed Sci Technol, 27, 77-89.

Bonjovani, M. R.; Barbedo, C. J. (2008), Sementes recalcitrantes: intolerantes a baixas temperaturas? 
Embriões recalcitrantes de Inga Vera Willd. subsp. affinis (DC.) T.D. Penn. toleram temperatura subzero. Rev Bras Bot, 32, 345-356.

Borges, I. F.; Del Giudice Neto, J.; Bilia, D. A. C.; Figueiredo-Ribeiro, R. C. L. and Barbedo, C. J. (2005), Maturation of seeds of Caesalinia echinata Lam. Brazilwood), an endangered leguminous tree from the Brazilian Atlantic Forest. Braz. arch. biol. technol., 48, 851-861.

Borges, I. F.; Barbedo, C. J.; Richter, A. A.; Figueiredo-Ribeiro, R. C. L. (2006), Variations in sugars and cyclitols during development and maturation of seeds of brazilwood (Caesalinia echinata Lam., Leguminosae). Braz J Plant Physiol, 18, 475-482.

Corte, V. B.; Borges, E. E. L.; Pontes, C. A.; Leite, I. T. A.; Ventrella, M. C.; Mathias, A. A. (2006), Mobilização de reservas durante a germinação das sementes e crescimento das plântulas de Caesalpinia peltophoroides Benth. (LeguminosaeCaesalpinoideae). Rev Árvore, 30, 941-949.

Crowe, J. H.; Carpenter, J. F.; Crowe, L. M.; Anchordoguy, T. J. (1990), Are freezing and dehydration similar stress vectors? A comparison of modes of interaction of stabiling solutes with biomolecules. Cryobiology ,27, 219-231.

Delgado, L. F.; Barbedo, C. J. (2007), Tolerância à dessecação de sementes de espécies de Eugenia. Pesq Agrop Bras, 42, 265-272.

Dubois, M.; Gilles, A.; Hamilton, J. K.; Rebers, P. A.; Smith, F. (1956), Colorimetric method for determination of sugars and related substances. Anal Chem, 28, 350-355.

Dyer, J. M.; Stymne, S.; Green, A. G.; Carlsson, A. S. (2008), High-value oils from plants. Plant J, 54, 640655.

Faria, R. A. P. G.; Andrade-Neto, M.; Pinto, L. S.; Castellón, R. R.; Calvete, J. J.; Cavada, B. S. (2004), Caracterização química parcial e bioquímica de sementes de Bauhinia forficata link. Arch Latin Nutr, 54, 349-353.

Faria, J. M. R.; Davide, L. C.; Silva, E. A. A.; Davide, A. C.; Pereira, R. C.; van Lammeren, A. A. M.; Hilhorst, H. W. M. (2006), Physiological and cytological aspects of Inga vera subsp. affinis embryos during storage. Braz J Plant Physiol, 18, 475-485.

Garcia, I. S.; Souza, A.; Barbedo, C. J.; Dietrich, S. M. C.; Figueiredo-Ribeiro, R. C. L. (2006), Changes in soluble carbohydrates during storage of seeds of Caesalpina echinata Lam. (Brazilwood), an endangered leguminous tree from Brazilian Atlantic Forest. Braz J Biol, 66, 739-745.

Górecki, R. J.; Piotrowicz-Cieslak, A. I.; Lahuta, L. B.; Obendorf, R. L. (1997), Soluble carbohydrates in desiccation tolerance of yellow lupin seeds during maturation and germination. Seed Sci. Res., 7, 107115 .
Hedley, C. L. (2001), Carbohydrates in grain legume seeds. Improving nutritional quality and agronomic characteristics. CABI Publishing.

Hellmann, M. E.; Mello, J. I. O.; Figueiredo-Ribeiro, R. C. L.; Barbedo, C. J. (2006), Tolerância ao congelamento de sementes de pau-brasil (Caesalpinia echinata Lam.) influenciada pelo teor de água. Rev Bras Bot, 29, 93-101.

Hellmann, M. E.; Mello, J. I. O.; Barbedo, C. J.; Figueiredo-Ribeiro, R. C. L. (2008), Variações dos carboidratos de reserva de sementes de Caesalpinia echinata (pau-brasil) armazenadas sob diferentes temperaturas. Hoehnea, 35, 255-264.

Hincha, D. K.; Popova, A. V.; Cacela, C. (2006), Effects of sugars on the stability of lipids membranes during drying, in: Leitmannova Liu (Ed.), Advances in Planar Lipid Bilayers and Liposomes 3, 189-217.

Hoekstra, F. A.; Golovina, E. A.; Buitink, J. (2001) Mechanisms of plant desiccation tolerance. Trends Plant Sci, 6, 431-438.

Hor, Y. L.; Kim, Y. J.; Ugap, A.; Chabrillange, N.; Sinniah, U. R.; Engelmann, F.; Dussert, S. (2005), Optimal hydration status for cryopreservation of intermediate oily seeds: Citrus as a case study. Ann Bot, 95, 1153-1161.

Horbowicz, M.; Obendorf, R. L. (1994), Seed desiccation tolerance and storability: dependence on flatulence-producing oligosaccharides and cyclitols review and survey. Seed Sci Res, 4, 385-405.

Ista (1985) International rules for seed testing. Seed Sci Technol, 13, 356-513.

Kohama, S.; Maluf, A. M.; Bilia, D. A. C.; Barbedo, C. J. (2006), Secagem e armazenamento de sementes de Eugenia brasiliensis Lam. (grumixameira). Rev Bras Sementes, 28, 72-78.

Liu, M.-S.; Chang, C.-Y.; Lin, T.-P. (2006), Comparison of phospholipids and their fatty acids in recalcitrant and orthodox seeds. Seed Sci Technol, 34, 443-452.

Marega Filho, M.; Destro, D.; Miranda, L. A.; Spinosa, W. A; Carrão-Panizzi, M. C.. and Montalván, R. (2001), Relationships among oil content, protein content and seed size in soybeans. Braz. arch. biol. technol., 44, 23-32.

Matuda, T. G.; Maria-Netto, F. (2005), Caracterização química parcial da semente de jatobá-do-cerrado (Hymenaea stigonocarpa Mart.). Cienc. Tecnol. Aliment., 25, 353-357.

Mayer, A. M.; Poljakoff-Mayber, A. (1980), The germintation of seeds. New York : McMillan.

Mayworm, M. A. S.; Nascimento, A. S.; Salatino, A. (1998), Seeds of species from the "caatinga": proteins, oils and fatty acid contents. Rev Bras Bot, 21, 961-972.

Mello, J. I. O.; Barbedo, C. J. (2007), Temperatura, luz e substrato para a germinação de sementes de paubrasil (Caesalpinia echinata Lam., Leguminosae Caesalpinioideae). Rev Árvore, 31, 645-655. 
Moraes, R. M. A.; José, I. C.; Ramos, F. G.; Barros, E. G.; Moreira, M. A. (2006), Caracterização bioquímica de linhagens de soja com alto teor de proteína. Pesq Agropec Bras, 41, 715-729.

Navari-Izzo, F.; Quartacci, M. F.; Izzo, R. (1989), Lipid changes in maize seedlings in response to field water deficits. J Exp Bot, 40, 675-680.

Nkang, A. (2002), Carbohydrate composition during seed development and germination in two subtropical rainforest tree species (Erythrina caffra and Guilfoylia monostylis). J Plant Physiol, 159, 473-483.

Ortega-Nieblas, M.; Vasquez-Moreno, L.; RoblesBurgueño, M. R. (1996), Protein quality and antinutritional factors of wild legumes seeds from the Sonoran Desert. J. Agric. Food Chem., 44, 31303132.

Paula, F. M.; Thi, A. T. P.; Silva, J. V.; Justin, A. M.; Demandre, C. (1990) Effects of water stress in the molecular species composition of polar lipids from Vigna unguiculata L. leaves. Plant Sci, 66, 185-193.

Peterbauer, T.; Richter, A. (2001) Biochemistry and physiology of raffinose family oligosaccharides and galactosyl cyclitols in seeds. Seed Sci Res, 11, 185197.

Pinto, L. S.; Andrade-Neto, M.; Bacarin, M. A.; Castellón, R. R.; Gadelha, T. S.; Gadelha, C. A.; Cavada, B. S. (2005) Caracterização química e bioquímica de sementes de Bauhinia variegata L. Rev Bras Eng Agric Amb, 9, 385-390.

Pritchard, H. W.; Haye, A. J.; Wright, W. J.; Steadman, K. J. (1995), A comparative study of seed viability in Inga species: desiccation tolerance in relation to the physical characteristics and chemical composition of the embryo. Seed Sci Technol, 23, 85-100.

Quartacci, M. F.; Forli, M.; Rascio, N.; Dalla-Vecchia, F.; Bochicchio, A.; Navari-Izzo, F. (1997), Desiccation-tolerant Sporobolus stafianus: lipid composition and cellular ultrastructure during dehydration and rehydration. J Exp Bot, 48, 12691279.

Santos-Mendoza, M.; Dubreucq, B.; Baud, S.; Parcy, F.; Caboche, M.; Lepiniec, L. (2008), Deciphering gene regulatory networks that control seed development and maturation in Arabidopsis. Plant $J$, 54, 608-620.
Sershen; Berjak, P.; Pammenter, N. W. (2008), Desiccation sensitivity of excised embryonic axes of selected amaryllid species. Seed Sci Res, 18, 1-11.

Silva, T. R. G.; Cortelazzo, A. L.; Dietrich, S. M. C. (1998), Variations in storage compounds during germination and early plantlet growth of Dalbergia miscolobium. Rev Bras FisiolVeg, 10, 119-124.

Sotelo, A. (1996), The nutritive value of wild Mexican legumes with a potential for nutritional use. Nwokolo $\mathrm{E}$ and Smartt J (ed.). Food and feed from legumes and oil seeds. Chapman and Hall. p. 33-48.

Takemoto, E.; Okada, I. A.; Garbelotti, M. L.; Tavares, M.; Aued-Pimentel, S. (2001), Composição química da semente e do óleo de baru (Dipteryx alata Vog.) nativo do município de Pirenópolis, Estado de Goiás. Rev Inst Adolfo Lutz, 60, 113-117.

Vadivel, V.; Janardhanan, K. (2001), Nutritional and anti-nutritional attributes of the under-utilized legume, Cassia floribunda Cav. Food Chem 73, 209215.

Vallilo, M. I.; Tavares, M.; Aued-Pimentel, S.; Garbelotti, M. L. (2001), Caracterização química parcial das sementes de Lonchocarpus muehlbergianus Hass. Rev Inst Adolfo Lutz, 60, 1722.

Yancey, P. H.; Clark, M. E.; Hand, S. C.; Bowlus, R. D.; Somero, G. N. (1982), Living with water stress: evolution of osmolyte systems. Science, 217, 12141222 .
Received: November 13, 2008; Revised: June 24, 2009; Accepted: November 03, 2009. 